\title{
The Gulper and the Slurper: A Lexicon of Mistakes to Avoid While Eating with Ottoman Gentlemen
}

\author{
Helen Pfeifer \\ Faculty of History, University of Cambridge \\ hp379@cam.ac.uk
}

\begin{abstract}
This article examines the material culture and social etiquette of elite dining in the early modern Ottoman Empire. The challenges of eating with others were numerous, as the sixteenth-century Damascene scholar Badr al-Din al-Ghazzi (d. 1577) showed in painful and hilarious ways in his treatise entitled Table Manners (Adab al-Mu'akala). One set of problems stemmed from the objects structuring the meal, especially the relative dearth of crockery and cutlery. Far from making dining experiences simpler and more straightforward, as scholars have sometimes suggested, this necessitated greater cooperation between diners and made them vulnerable to individual misbehavior. Another set of problems arose from the material qualities of food, where sources of pleasure, handled poorly, could easily trigger disgust. The self-discipline that Ghazzi promoted in his manual offered a partial solution to these difficulties, but not a solution equally available to all.
\end{abstract}

\section{Keywords}

Ottoman Empire - material culture - food - etiquette - the body - social status

\section{Introduction}

There must be more than a thousand ways to torment others at the dinner table, but the sixteenth-century Damascene scholar Badr al-Din al-Ghazzi contented himself with enumerating eighty-one in his treatise on Table Manners. Gluttony surfaces as an ever-present problem at the elite banquets that are the implied subject of Ghazzi's conduct manual, rearing its ugly head as the 
lump in the cheek of the one whose bites were too big or as the silence of the one whose grim determination to eat could not be derailed by small talk. Stinginess, too, often took a seat at the Ottoman table, especially, to judge from the treatise, at its head: there were hosts who offered tiny portions and lectured on the benefits of dieting; hosts who started conversations so demanding that their guests could not concentrate on the food; and hosts who served legumes and other inexpensive foods for hours, so that the guests were full by the time the meat arrived. Such issues were hardly unique to sixteenth-century Ottoman society. However, the material aspects of early modern Ottoman tables gave these run-of-the-mill problems a special form, if not even a special urgency. Specifically, these aspects meant that the misbehavior of one diner could disproportionately affect others.

This article examines how the material culture of food helped to shape dining experiences and dining etiquette in the sixteenth-century Ottoman Empire. Recent studies of material culture have emphasized that objects are not just products of social relations but help to structure them; while meeting certain social needs, they also create new ones. However, much of this work has been based primarily on the European experience. While the "civilizing process" posited by Norbert Elias has been roundly criticized if not totally debunked, the package of developments he identified remain strong in our narratives of early modern eating: the move from a heavy reliance on the fingers to specialized implements that kept the hands clean; from shared dishes to individualized plates; and from a society with few prohibitions to a more complex sociability characterized by shame and restraint. ${ }^{1}$ Studying Middle Eastern dining culture, which underwent material transformations different from those in European lands, allows us to test some of our assumptions concerning the relationship between objects and etiquette. ${ }^{2}$

Ghazzi's Table Manners (Adab al-Mu'akala) offers a modest but entertaining window onto some of these questions. Although it was based on an existing literary tradition, comparing it to its predecessors indicates that it was updated to accord with the sixteenth-century social world. Although its circulation

1 Norbert Elias, The Civilising Process: Sociogenetic and Psychogenetic Investigations, trans. Edmund Jephcott (Malden, MA, 200o), esp. 58-121.

2 For an overview of the historiography on Ottoman food, see Özge Samancl, "Food Studies in Ottoman-Turkish Historiography," in Writing Food History: A Global Perspective, eds. Kyri Claflin and Peter Scholliers (London, 2012), 107-120. Research published since then includes Suraiya Faroqhi, A Cultural History of the Ottomans: The Imperial Elite and its Artefacts, (London, 2016), ch. 6; Amanda Phillips, Everyday Luxuries: Art and Objects in Ottoman Constantinople, 160o-180o (Dortmund, 2016), ch. 2; Priscilla Işın, Bountiful Empire: A History of Ottoman Cuisine (London, 2018). 
was limited, triangulating it with the material and visual record as well as with advice offered in the Turkish-language Sublime Ethics (Ahlak-ı 'Ala'i) written by the Istanbul-educated scholar Kinalızade 'Ali (d. 1572) suggests that many aspects of the food culture Ghazzi described could be found not just in Ghazzi's hometown of Damascus but in other parts of the Ottoman Empire as well. ${ }^{3}$

Some of the issues Ghazzi addressed were responses to physical and physiological aspects of the human body - these resonate with the feelings of shame vis-à-vis natural functions that Elias argued arose in Europe in the early modern period. ${ }^{4}$ But many other of Ghazzi's concerns resulted from the specific ways that inhabitants of the early modern Middle East ate, especially their use of fewer objects at mealtimes and their propensity to share dishes. It might be assumed that simpler tables made for a 'simpler' sociability. Instead, Ghazzi's manual suggests that it in some ways acted to heighten the social proficiency needed to survive a lavish banquet, ultimately helping to make Ottoman society more socially exclusive.

\section{The Treatise on Table Manners}

Muhammad Badr al-Din al-Ghazzi (1499-1577) was one of the foremost intellectuals of sixteenth-century Damascus and a known figure in elite circles across Ottoman lands. Born into a distinguished family and educated in Cairo, Ghazzi was only sixteen when the Ottomans took over what had been Mamlukcontrolled Syria, Egypt and the Arabian Peninsula in 1516-1517; he spent his adult life in a rapidly Ottomanizing Damascus keeping close contact with the Istanbul-trained imperial elite. Table Manners, which is undated, is hardly one of his more popular writings; it seems to exist in only one copy today-though not in autograph copy_and was not included in contemporary lists of his

3 It is in light of these parallels, as well as Ghazzi's close contact with the centrally-trained elite, that this article takes the treatise as offering insight into "Ottoman" dining culture more broadly. Kınalı-zâde Alî Çelebi, Ahlâk-ı Alầî: Tıpkıbasım, ed. Fahri Unan (Ankara, 2011), fols. 215b-216b; Ayşe Sıdıka Oktay, Kınalızâde Ali Efendi ve Ahlâk-ı Alầ, (Istanbul, 2011), 395-399; Louise Marlow, "Advice and Advice Literature," in Encyclopaedia of Islam Three, eds. Kate Fleet et al., consulted online on 17 August 2019 http://dx.doi.org/10.1163/1573-3912_ei3_ COM_0026. There was a long history of culinary exchanges across the Middle East, leading to broad similarities in cuisine and etiquette. Işın, Bountiful Empire, 11-38.

4 Elias, Civilizing Process, 114-121. 
most important publications. ${ }^{5}$ Still, it fits well into his larger oeuvre, which featured a number of other conduct manuals as well. ${ }^{6}$

Table Manners is also one of Ghazzi's more light-hearted works. Less than twenty manuscript pages in length, it consists of a three-line introduction followed by a list of eighty-one errors to avoid while eating with others. This already makes for good fun, since Ghazzi eschews the serious, didactic tone of the traditional conduct manual in favor of the comedy of errors that results when its dictates are ignored. But what makes the piece even more entertaining is that it is presented in the guise of a lexicon. Each error is personified as a particularly abhorrent species of repeat offender. This means that, although the manual is supposed to be instructive, it is also very funny. Much of its humor derives from the way it plays with words, since many of its terms are new coinages. The delivery of these neologisms in the measured, scientific tone of the lexicon only compounds the satisfaction of the reader. ${ }^{7}$

However, there is no doubt that Ghazzi was entirely serious about the precepts his manual introduced. One of the great advantages of the lexicon genre was that it presented his rules as timeless and hence absolute. And indeed, like most good advice writers, Ghazzi rarely referred to particular times and places - and when he did, they were exemplary places, like the court of the Abbasid Caliph al-Ma'mun (r. 813-833), known for his interest in art and culture. ${ }^{8}$ Ghazzi occasionally drew on the words and deeds of the Prophet Muhammad - an important source of etiquette in Islamic contexts-but one of the things that distinguishes his text from many others is how little explicit religious content it contains. ${ }^{9}$

5 This article is based on 'Umar Musa Basha's printed edition, which is based on a manuscript in his private collection. 'Umar Musa Basha, Risalat Adab al-Mu'akala (Rabat, 1984). For a discussion, see Geert Jan van Gelder, "Arabic Banqueters: Literature, Lexicography and Reality," in Rika Gyselen (ed.), Banquets d'Orient (Res Orientales IV) 1992: 85-93, esp. 89-90. Another article on Table Manners was published when this one was in its final stages and could thus not be fully considered. Tarek Abu Hussein, "Social Dining, Banqueting, and the Cultivation of a Coherent Social Identity: The Case of Damascene 'Ulama' in the Late Mamluk and Early Ottoman Period," in Insatiable Appetite: Food as a Cultural Signifier, eds. Kirill Dmitriev and Bilal Orfali (Leiden, 2019): 11-26.

6 For a brief introduction to Ghazzi, see Ralf Elger, "Badr al-Dīn Muḥammad al-Ghazzī," in Essays in Arabic Literary Biography, 1350-1850, eds. Joseph Lowry and Devin Stewart (Wiesbaden, 2009), 98-106.

7 Gelder, "Banqueters," 88. Basha notes the similarities to a section of al-Tha'alibi's (d. 1039) lexicon. Basha, "Appendix," Risala, 52-54; Abu Mansur al-Tha'alibi, Figh al-Lugha wa Sirr al'Arabiyya, ed. Yasin al-Ayyubi (Beirut, 2000), 183.

8 Ghazzi, Risala, 15, 22-24; also 16, 34, 48-49.

9 Basha, "Introduction," Risala, 11. 
Nonetheless, Ghazzi relied heavily on literary precedent in drafting his treatise. There was a long history of writing about dining etiquette in the Islamic tradition, and Ghazzi's recommendations were usually in keeping with those offered by earlier authors. ${ }^{10}$ But there was even a subset of advice literature that included personified lists of dining errors exactly like Ghazzi's. The form dated back several centuries to the famous Abbasid litterateur al-Jahiz (d. 868), who included such a list in his great literary anthology The Book of Misers (Kitab al-Bukhala $).{ }^{11}$ The list was an instant hit, and portions of it were incorporated into the works of at least four other authors working between the tenth and fifteenth centuries. ${ }^{12}$

Does all of this mean that Table Manners was a historical relic in its own time, fished out of the recycling bin and useless for the historian of Ghazzi's era? It seems not. However similar some of Ghazzi's prescriptions were to those of earlier writers, he did not shy away from contradicting their advice when necessary, as we will see below. As for the earlier lists in a similar style, though Ghazzi did take inspiration from them, he only rarely copied them outright, as a systematic comparison of his list with the other five suggests. For three of his lexical entries, Ghazzi did lift his text from one of the older ones word-forword. ${ }^{13}$ For eleven others, he borrowed an existing term but made significant changes to the accompanying definition (often updating it to reflect changes in etiquette or material culture). ${ }^{14}$ Ghazzi's remaining sixty-seven errors do not

10 E.g. Ibn al-Hajj (d. 1336) and Aqfahsi (d. 1406). Muhammad Ibn al-Hajj, al-Madkhal (Cairo, n.d.), 1:216-237; Ibn al-'Imad al-Aqfahsi, Adab al-Akl, eds. 'Abd al-Ghaffar al-Bandari and Abu Hajar Zaghlul (Beirut, 1987), 21, 28-30. For a discussion, see Paulina Lewicka, Food and Foodways of Medieval Cairenes: Aspects of Life in an Islamic Metropolis of the Eastern Mediterranean (Leiden, 2011), 432-453. For the broader tradition of which these were all a part, see Geert van Gelder, "Taām," in Encyclopaedia of Islam, Second Edition, eds. Bearman et al., consulted online on 27 January 2012 http://www.brillonline.nl/subscriber/ entry?entry=islam_SIM-7240; idem, God's Banquet: Food in Classical Arabic Literature (New York, 200o), esp. 46; Lewicka, Food, 387-403.

11 Gelder, "Arabic Banqueters," 87-92; Jahiz, Kitab al-Bukhala' (Cairo, n.d.), 76-78.

12 Ibn 'Abd Rabbih (d. 940), Ahmad al-Jurjani (d. 1089), Yahya al-Jazzar (d. 1270 or 1281), and Muhammad al-Ibshihi (d. 1446). Ibn 'Abd Rabbih, al-'Tqd al-Farid, ed. Muhammad Qumayha, (Beirut, 1983), 2:291-2; Ahmad al-Jurjani, Kinayat al-Udaba' wa Isharat alBulagha', ed. Mahmud Shakir al-Qattan, (Cairo, 2003), 315-316; Yahya al-Jazzar, Fawa'id al-Mawa'id, MS London, British Museum, Or. 6388, fols. 12b-13b; Muhammad al-Ibshihi, al-Mustatraf fi Kull Fann Mustazraf (Beirut, 1992), 1:269-70. For the first two, see Gelder, "Arabic Banqueters," 88 n. 23; for Jazzar, see Lewicka, Food, 390, 436-437; for Ibshihi, see Gelder, God's Banquet, 46; Lewicka, Food, 389-39o.

13 Al-jarrāf, al-bahhāt, and al-murannikh. Ghazzi, Risala, 24, 35, 39; Jazzar, Fawa’id, fols. 13ab; Ibshihi, al-Mustatraf, 270.

14 (1) al-mașșāss, (2) al-lattāc, (3) al-daffāc, and (4) al-jardabïl are shared with Jahiz; (5) alzaḥhāf (called al-zāhị by Ghazzi), (6) al-muwassikh, (7) al-naffākh, and (8) al-mughaththī 
appear in any of the other five works consulted here. ${ }^{15}$ To be sure, some of his text may still have derived from Jahiz's original list, which was longer than what remains of it today; there might well be other lists on which Ghazzi drew, lost or unknown to me. Still, until further research unearths such lists, it seems fair to assume that Ghazzi did in fact write much of his text himself, and that even when he did reuse earlier material, he did so only insofar as he found it applicable to his own day.

Ghazzi had plenty of communal dining experiences during which to take note of the shortcomings in his contemporaries' eating habits. ${ }^{16}$ However, he may also have had significant reason to try to reform them. Ghazzi's lifetime saw a dramatic increase in geographic and social mobility in the Middle East as imperial expansion brought different ethnic groups into new contact with one another and new wealth to different sectors of society. This meant that gentlemen like Ghazzi were increasingly faced with table companions whose origins might have bequeathed them different manners. Ghazzi's manual may well have been a response to this state of affairs — an attempt to bring the table back to order.

\section{The Trouble with the Table}

The period between 1400-1800 saw an expansion in the world of consumer goods in many parts of Eurasia, and the Middle East was no exception. As chairs, birthing trays, and rosaries proliferated in different sizes and shapes in Europe, the Ottoman Empire witnessed the introduction of cushion covers made of gold-brocaded silk velvet, close-fitting cloaks decorated with fur, and gold and silver hair accessories that hung down to a woman's heels. ${ }^{17}$ At

with Jazzar; (9) al-rashshāf, (10) al-mukhallil (called al-mutakhallil by Ghazzi), and (11) al-murashshish with Jazzar and Ibshihi.

15 Sometimes the idea is the same but the name different, e.g. al-mumtadd (cf. Jazzar and Ibshihi's al-'awwām) and al-mumtahin (cf. their al-mufattish).

16 Ibn Ayyub, Al-Rawd al-Atir fima Tayassara min Akhbar Ahl al-Qarn al-Sabi' ila Khitam al-Qarn al-Ashir, Berlin State Library, Wetzstein II 289, 242b; Najm al-Din al-Ghazzi, AlKawakib al-Sa'ira bi-A'yan al-Mi'a al-'Ashira 2nd ed., Jibra'il Jabbur (ed.), (Beirut, 1979), 3, 5-6.

17 Victoria Avery, Melissa Calaresu, and Mary Laven (eds.), Treasured Possessions from the Renaissance to the Enlightenment (London, 2015); Amanda Phillips, "A Material Culture: Ottoman Velvets and their Owners, 1600-1750," Muqarnas: An Annual on the Visual Cultures of the Islamic World, 31 (2014): 151-172; Eminegül Karababa, "Investigating Evarly Modern Ottoman Consumer Culture in the light of Bursa Probate Inventories," Economic History Review, 65, no. 1 (2012): 194-219. 
the table, the Ottomans shared in the global craze for Chinese porcelain as well as in the increasingly sophisticated attempts to imitate it. ${ }^{18}$ So too were Ottoman gentlemen and women interested in intensifying their eating experiences by using precious objects; some sipped soup from spoons made of finely lacquered sandalwood with mother-of-pearl inlays (see figure 1). In some matters of food consumption, inhabitants of the Middle East even led the early modern consumer revolution, introducing Europeans not only to coffee but to the cups used to consume it.

Ghazzi's manual testifies to some of the changes underfoot. Though spoons had long been known in the Islamic Middle East, in the fourteenth century they could still be the subject of debate, with the deeply conservative and slightly hysterical Cairo-based scholar Ibn al-Hajj (d. 1336) decrying them as unnecessarily extravagant and above all unhygienic, since using them during communal meals meant that saliva would be spread to the shared dish. ${ }^{19}$ This same scholar condemned the low table (khiwān) as an impermissible innovation (bid'a), with the argument that the Prophet Muhammad had seen it fit to eat on a mat or the floor. ${ }^{20}$ By the sixteenth century, these items seem to have become totally acceptable, since Ghazzi—a deeply pious man himselfmentioned them unproblematically. ${ }^{21}$

Despite the introduction of new items, early modern Ottoman tables would have appeared sparse next to most modern tables. First of all, there was not even always a table, at least not in the strict sense of that word. Although the phrase a àdäb al-mu'ākala in Ghazzi's title is commonly translated as "table manners," its literal meaning is closer to "manners for eating together." To be sure, people often took their meals from a low table or a tray called a sinni, the latter usually made of copper and posed on a wooden stand. But it did not take a religious zealot to gather his family or friends together around the large leather mat (Ar. sufra, Tur. sofra) of which Ibn al-Hajj was a proponent (see figures $3 \& 4) .{ }^{22}$ In any case, diners usually did not sit on chairs to eat, but

18 Julian Raby and Ünsal Yücel, "Chinese Porcelain at the Ottoman Court," in Chinese Ceramics in the Topkapı Palace, ed. Regina Krahl (London, 1986), vol. 1, 27-54; Walter Denny, Iznik: The Artistry of Ottoman Ceramics (London, 2004).

19 Ibn al-Hajj, Madkhal, vol. 1, 223. It is not clear how widely spoons were used in medieval Cairo. Lewicka, Food, 432-433. For Ibn al-Hajj see Jonathan Berkey, "Tradition, Innovation and the Social Construction of Knowledge in the Medieval Islamic Near East," Past and Present 146 (1995): 38-65.

$20 \quad$ Ibn al-Hajj, Madkhal, 1:226; Lewicka, Food, 417, n 118.

21 He uses māida, not khiwān.

22 Faroqhi, Cultural History, 156. See also Lewicka, Food, 414-417; De Villamont, Voyages, 675 . 

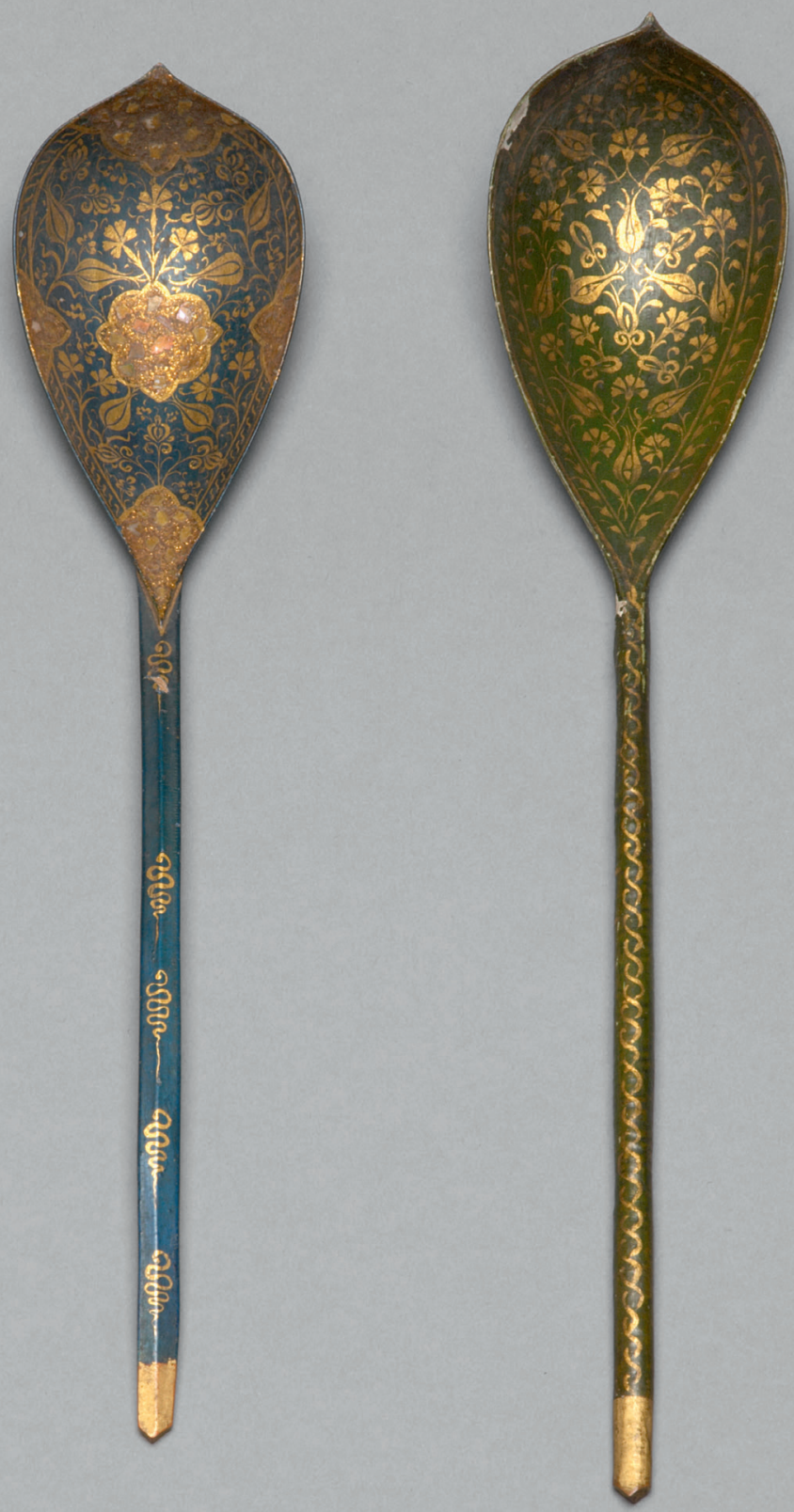

FIGURE 1 Ottoman spoons. Lacquered wood with mother-of-pearl, $27 \mathrm{~cm} \& 29 \mathrm{~cm}$, second half of the sixteenth century. KHM-Museumsverband, AM PA 777. 


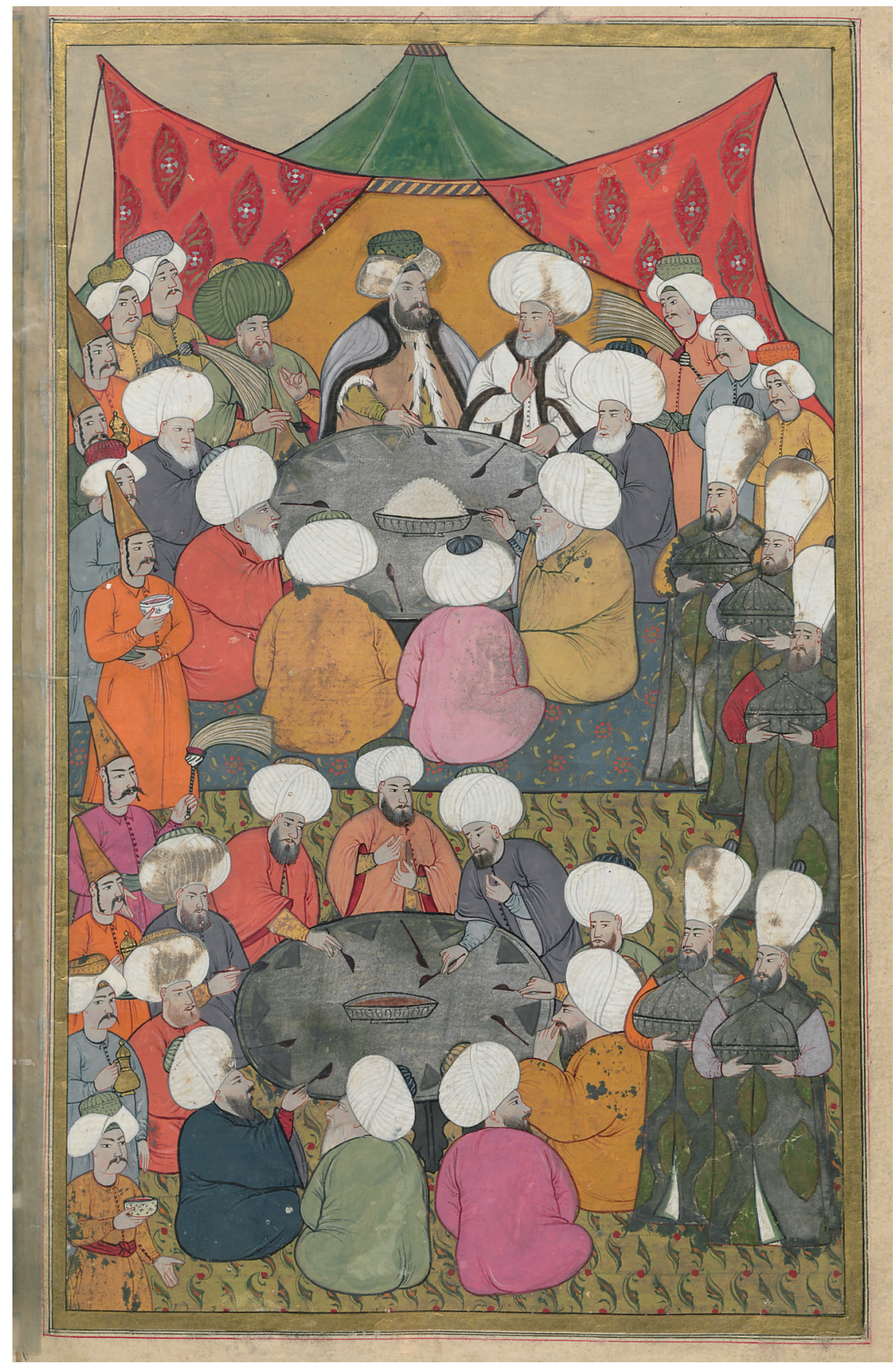

Figure 2 A feast with the scholars. Levni, The Festival Book of Vehbi, ca. 1730. Topkapı Palace Museum Library, A 3593, fol. 49b. 


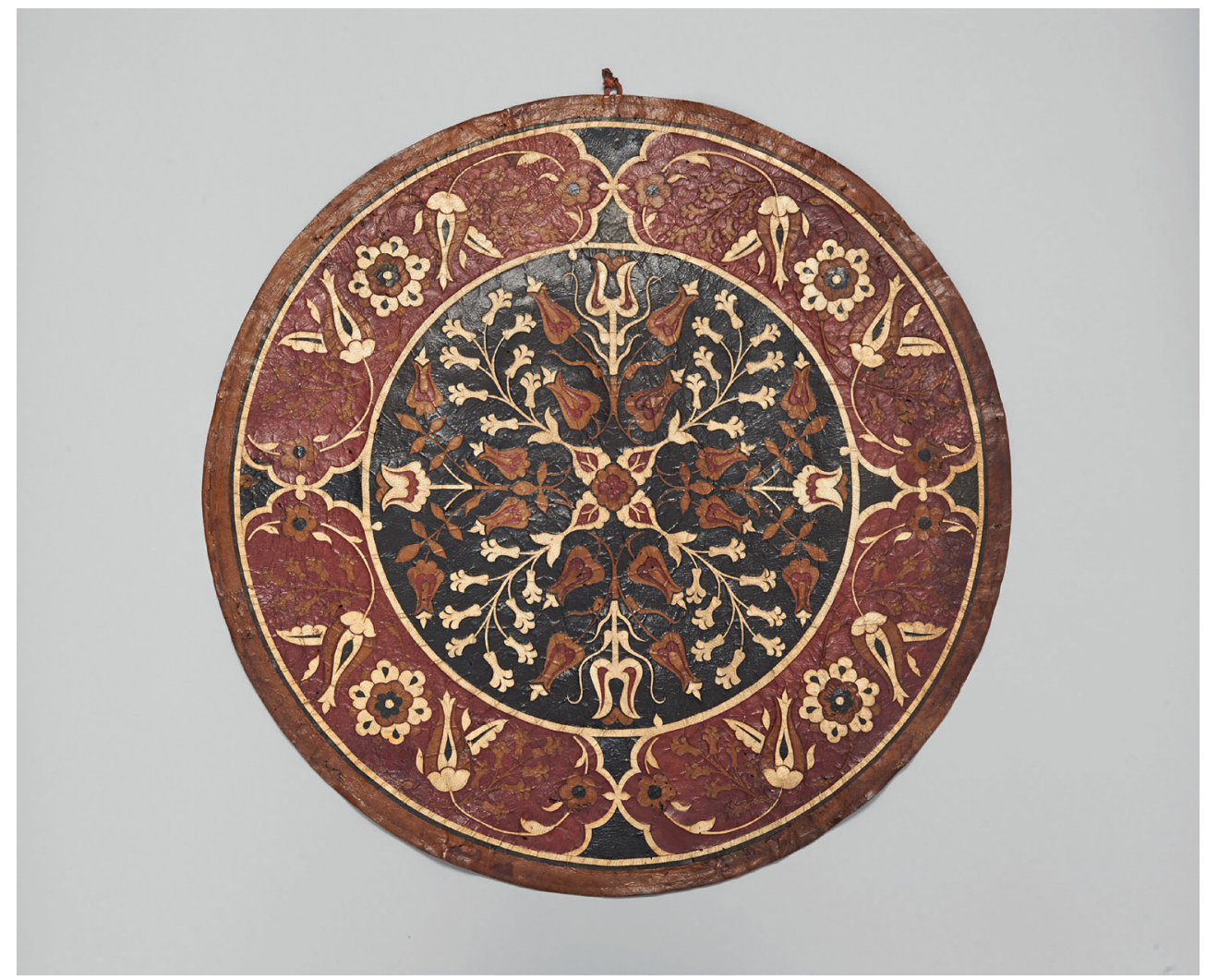

FIGURE 3 Ottoman leather mat for eating (sofra). Goatskin leather, $5^{0.8} \mathrm{~cm}$, second quarter of the sixteenth century. КнM-Museumsverband, AM PA 560.

rather on carpets spread across the floor (see figures $2 \& 6$ ). ${ }^{23}$ Second, the tops of these eating surfaces were usually less cluttered than they often are today. Other than spoons, cutlery was sparse (see figure 2). Knives were not normally brought to the table, and forks were certainly not used. ${ }^{24}$ For the most part, food was prepared in such a way that it could be eaten with a piece of bread or with the hand (see figure 2).

Eating in this way had many benefits. Unlike the unwieldy furniture common in European homes, Ottoman mats and tables were light and rarely permanently installed in a particular location. This allowed for a more flexible use of living spaces and made it easier to take one's meal outside or while traveling.

23 De Villamont, Voyages, 675 .

24 Ghazzi, Risala, 28; de Villamont, Voyages, 675-676; Lewicka, Food, 432. 


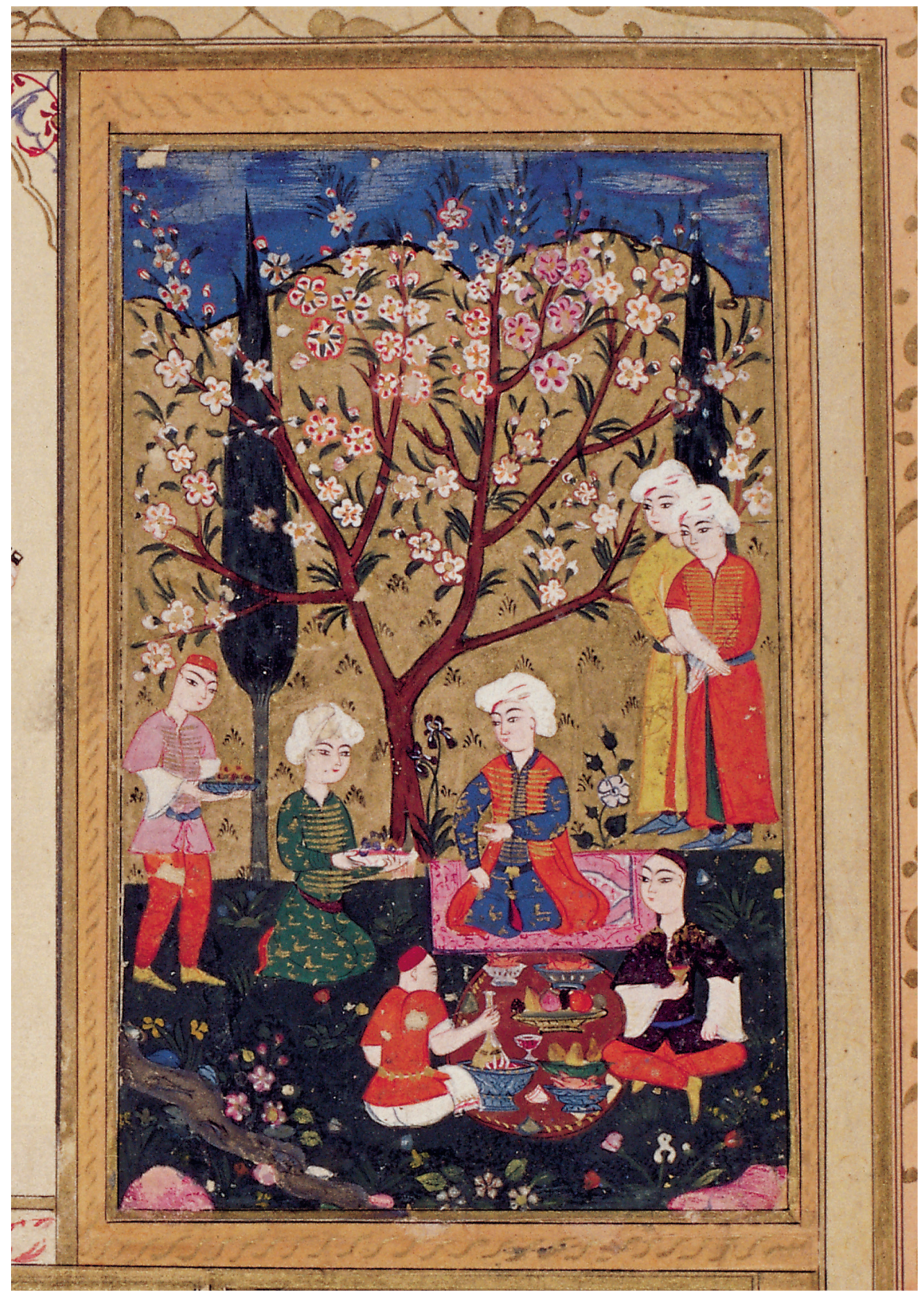

FIgure 4 A picnic. Kalender, Album of Ahmed I, ca. 1610. Topkapı Palace Museum Library, B 408, fol. 16a. 
Using fewer utensils had its upsides too, since eating with one's fingers adds an additional dimension to the sensory pleasure evoked by eating. ${ }^{25}$

One might assume that the final benefit of fewer objects was that it made eating more straightforward: you didn't have to worry about when or how to use which piece of cutlery if all you had in front of you was a spoon. Indeed, in many narratives based on the European experience, the increasing proliferation and specialization of objects in the early modern period has been seen as linked to the growing complexity of rituals of sociability. According to Elias, new objects like forks reflected a culture that was developing more rigorous standards of politeness and a heightened sense of shame. ${ }^{26}$ Mimi Hellman has shown beautifully how the increasingly intricate material world of eighteenthcentury France necessitated new knowledge and new behaviors on the part of their users. Building on the work of Elias, she argues even more forcefully that the complexity of sociability was a function of the complexity of objects. ${ }^{27}$ Does that then mean that the Ottoman Empire, with its sparser, and often quite simple furnishings, gave rise to simpler sociability?

Ghazzi's manual suggests that it did not. As anyone who has tried to walk a tightrope knows, simple objects are not necessarily simple to use. To the contrary, as the case of bread suggests: the problem with these flat but bendable objects, from Ghazzi's perspective at least, was how flexible they were. Unlike, say, a fork, whose form was highly determinate of what one could do with it, a piece of flatbread did not precisely determine the way that it could be used. One simply had to know that although one could, in principle, use a piece of bread like a napkin or a spoon, it was not considered polite to do so. Far from reducing the knowledge required to manipulate an object, an object's simplicity could actually heighten it.

What's more, the lack of specialized implements at the table meant more reliance on that most versatile tool of all: the body. Like all tools, this one required knowledge to manipulate properly. Without chairs to model—indeed force-a certain way of sitting, it was all the more important that one practiced correct posture, something that occupied late medieval writers of table

\footnotetext{
25 Anna Mann et al., "Mixing Methods, Tasting Fingers: Notes on an Ethnographic Experiment," HAU: Journal of Ethnographic Theory 1, no. 1 (2011): 221-243.

26 Elias, Civilizing Process, esp. 107-109.

27 Mimi Hellman, "Furniture, Sociability, and the Work of Leisure in Eighteenth-Century France," Eighteenth-Century Studies 32, no. 4 (1999): 415-445, esp. 437. Ajmar-Wollheim writes, "arguably, specialization in the seating available in the house ... actively contributed to regulate and support sociability." Marta Ajmar-Wollheim, "Sociability," in At Home in Renaissance Italy, eds. Ajmar-Wollheim and Flora Dennis (London, 2006), 208.
} 
manners and that Ghazzi discussed at length in other etiquette manuals. ${ }^{28}$ And of course, without a knife and fork, it was all the more important that one moved one's hands correctly.

Ghazzi paid a lot of attention to the way in which one should use one's hands for eating — or rather, not use one's hands. Unless one had some sort of special condition or disability, one was always to eat with two hands, rather than to break the bread by bending it over onto itself or puncturing it with the nail as "the one-armed man" (al-akta) did. ${ }^{29}$ Food should be lifted with three fingers, avoiding the ways of those who only pretended to do so while in fact using all five of them or even the palms of their hands. ${ }^{30}$ The bite should then be released delicately at the lips, avoiding the indecorous ways of "the shoveler" (al-daff $\left.\bar{a}^{\top}\right)$, who, "if he puts a bite of food in his mouth, the tips of his fingers go with it, as if he were pushing it in with them." ${ }^{31}$

Some of these offenders were conniving sorts who knew the rules full well but broke them to get more food. But others simply lacked what Marcel Mauss called the "techniques of the body" (techniques du corps) to fulfill those expectations. These techniques of bodily comportment, far from biologically determined, are the product of a particular habitus developed through a particular upbringing. ${ }^{32}$ That this kind of mastery over the body was a central concern for Ghazzi is suggested by the even more heinous relative of the shoveler, namely "the disgusting one" (al-mughaththī), who "smears his chin with grease because he has no control over his mouth or hand when he puts [food] into his mouth, so that everyone has to watch the grease dribbling down from his moustache."33 The problem, as Ghazzi's description of this sorry spectacle suggested, was that such improper technique did not simply harm the person whose poor breeding it reflected, but the other diners who had to witness such revolting scenes.

28 Badr al-Din al-Ghazzi, Al-Durr al-Nadid fi Adab al-Mufid wa-l-Mustafid, ed. Abu Yacqub Nash’at ibn Kamal al-Misri (2006), 194-195; Kınalı-zâde, Ahlâk, 213b-215b; Lewicka, Food, 421-424.

29 Ghazzi, Risala, 41. Cf. Ibn al-Hajj, who argued that eating with the left hand was only a thing for the devil. Ibn al-Hajj, Madkhal, vol. 1, 230.

3o Ghazzi, Risala, 41. Kınalızade also recommended eating with three fingers. Kınalı-zâde, Ahlâk, 215b. See also De Villamont, Voyages, 676 .

31 Ghazzi, Risala, 21.

32 Marcel Mauss, "Techniques of the body," trans. Ben Brewster, Economy and Society 2, no. 1 (1973): 70-88; Michael Dietler, "Feasting and Fasting," in The Oxford Handbook of the Archaeology of Ritual and Religion ed. Timothy Insolly (Oxford, 2011), 181. Ghazzi, Risala, 25 . 


\section{The Trouble with Sharing}

Beginning in the fourteenth century, it became more and more common in Europe to eat from individualized plates. ${ }^{34}$ Ottoman inhabitants did not begin to follow suit until the second half of the nineteenth century, and indeed there is no sign of such a practice in Ghazzi's manual. ${ }^{35}$ Instead, sharing was one of the key characteristics of the early modern Ottoman dining experience. This applied above all to the dishes themselves: diners might eat from one central dish or share a set of dishes with a group of neighbors (see figure 2). There is no evidence that they had individual plates on which to first deposit their food, although Ghazzi did speak of distributing the meat to the diners and earlier authors sometimes suggested that food could be temporarily placed on a piece of bread. ${ }^{36}$ Other items at the table might be shared as well, including napkins. A 1584 miniature depiction of an Ottoman military banquet features a semitransparent, embroidered napkin draped across the knees of the men sitting at the right edge of the table (figure 6), and European visitors often mentioned such long, shared napkins. ${ }^{37}$ A textile in Cambridge's Fitzwilliam collection may also be of that type or of the type mentioned by a seventeenth-century European traveler to Cairo when he explained that, after a meal, a cotton or linen napkin was circulated so that diners could wipe their hands and mouths (see figure 5$) \cdot{ }^{38}$ Certainly, at one and a half meters in length, the Fitzwilliam napkin offered enough surface area for several people.

Such sharing heightened the significance of communal eating. Through the thicket of blunders and wrong turns in Ghazzi's manual, it nonetheless emerges that sharing a dish, done properly, was a chance to strengthen social bonds. Part of this power derived from the physical proximity doing so cultivated between diners, necessarily bringing them into close quarters to ensure that everyone could reach the food. It could even mean an exchange of saliva, especially, as we have seen, if spoons were involved. Sharing dishes also

34 Reino Liefkes, "Tableware," in At Home, 256. Though even as late as the sixteenth century, individualized plates were not always the rule. Elias, Civilizing Process, 49-50.

35 Christian Saßmannshausen, "Eating Up: Food Consumption and Social Status in Late Ottoman Greater Syria," in Insatiable Appetite, 27-49; Özge Samancı, "Osmanlı Kültüründe Değişen Sofra Âdâbı: Alaturka-Alafranga İkilemi," Toplumsal Tarih (2013): 24-25.

36 Lewicka, Food, 429.

37 Jean de Thévenot, The Travels of Monsieur de Thevenot into the Levant (London, 1686), 33; Joseph Pitts, A True and Faithful Account of the Religion and Manners of the Mohametans (Exon, 1717), 18. See also Işın, Bountiful Empire, 55.

38 Antonius Gonzales cited in Lewicka, Food, 450 n. 278. Similar items feature in seventeenthand eighteenth-century Ottoman inventories. Phillips, Everyday Luxuries, 75. 


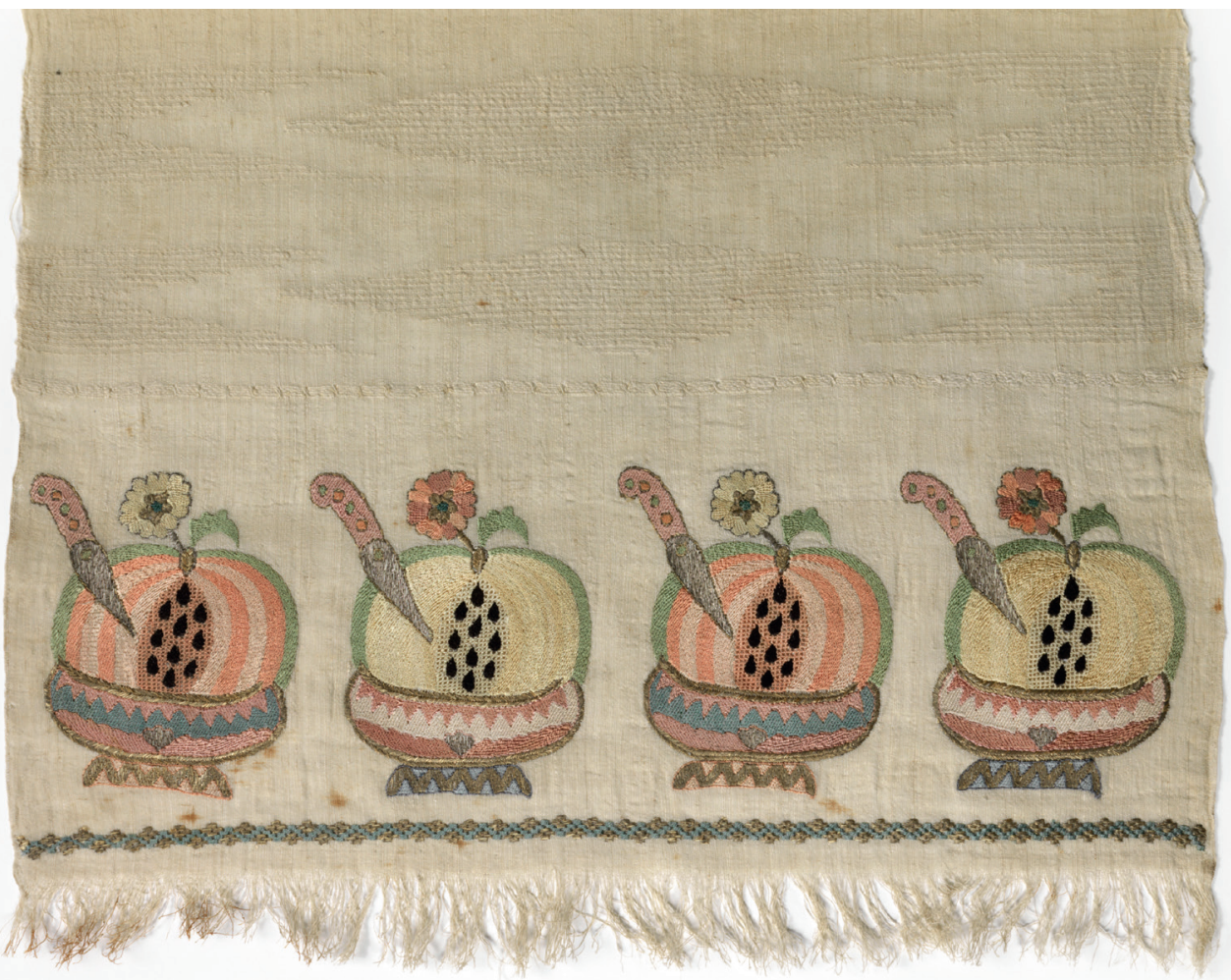

FIGURE 5 Ottoman napkin. Cotton embroidered with polychrome silk, gilt and silver thread, $162.5 \times 50.8 \mathrm{~cm}$, nineteenth century. Fitzwilliam Museum, Cambridge, T.81-1946. (C) The Fitzwilliam Museum, Cambridge.

allowed for, or even necessitated, displays of generosity or self-sacrifice. Hosts might set aside the choicest bit of meat for an especially esteemed guest. ${ }^{39}$ Yet even for guests, "the polite thing to do is to give [one's neighbor] preference in that which he finds delicious in terms of meat, and to offer him the drink first when taking a drink." ${ }^{40}$ Such actions could act as very concrete evidence of the gallantry of one man or his fond feelings for another.

However, the fact that dishes were shared made it all the more important that diners acted in accordance with social etiquette. Ghazzi described multiple ways that a perfidious and hungry man could ensure that he got the best or most servings. "The annihilator" (al-mukharrib) ploughed through bowls

39 Ghazzi, Risala, 28.

40 Idem, 27. Kınalızade concurred. Kınalı-zâde, Ahlâk, 216a. 


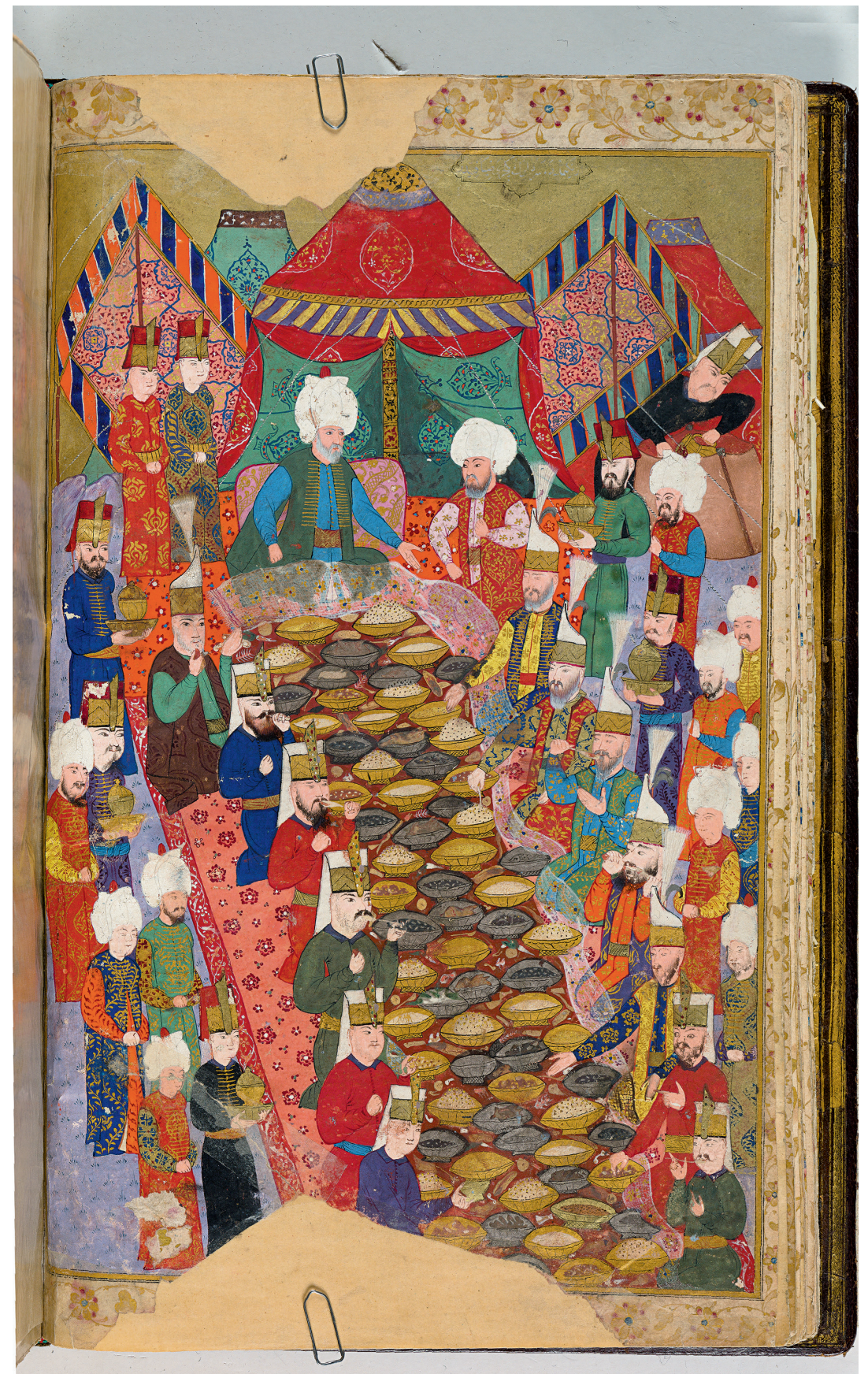

FIGURE 6 Ottoman military banquet. Mustafa 'Ali's Book of Victory, 1584. Topkapı Palace Museum Library, Hazine 1365, fol. 34b. 
taking the best bits of meat, leaving only scattered bones in his wake. ${ }^{41}$ "The trickster" (al-muhtāl) was much cleverer, since he did his work while appearing considerate and courteous: heaping piles of meat in front of his neighbor, when the neighbor politely protested, the trickster ate the meat himself- of course, having planned this outcome all along. ${ }^{42}$ The stakes were highest with meat, but bread caused similar problems. Some, seeing that supplies were dwindling, seized a large chunk to eat after the rest had been depleted..$^{43}$ Others clutched the entire loaf (raghiff) in their hands so that no one else could take any of it, gulping parts of it down ever more quickly as the bread ran out, even at the risk of choking. ${ }^{4}$

Sharing meals required diners to be extra attentive to other people's preferences. Unfortunately, there were many who were unaware of this fact or willfully ignorant of it. This is why "the meddler" (al-fudūuli) received one of Ghazzi's most extensive entries. He was the one who, seeing grilled lamb at the table, seized it and began tearing it into smaller pieces to distribute it amongst the guests, heedless of how the host had planned to apportion the meat out. Or the one who spread salt and pepper over the dishes, immune to the thought that some of the guests might prefer their food with less salt or take it with vinegar instead. "The best thing is not to go beyond modifying that which you yourself eat," Ghazzi counselled. ${ }^{45}$

Indeed, there was the ever-present danger of sharing too much. Since everyone was seated so close together, one had to work hard to avoid unwanted bodily contact. Woe was the guest who sat next to "the reacher" (al-mumtadd), "who eats from a little bowl that is far away from him, reaching out his arms toward it or moving closer to it." 46 Another concern was that saliva or other bodily fluids would be spread unnecessarily. This was presumably what was so dreadful about "the compulsive cutter" (al-muqați i) who took a bite of a morsel and then dipped the other half back into the dish. ${ }^{47} \mathrm{~A}$ more extreme form still was "the vomiter" (al-mutaqayya'), who pushed his food into his mouth as far back with his fingers as someone trying to induce himself to vomit would;

\footnotetext{
41 Idem, 27.

42 Idem, 47.

43 Idem, 31.

44 Idem, 31. Kınalızade also encouraged restraint if the food was limited. Kınalı-zâde, Ahlâk, 216a.

45 Ghazzi, Risala, 28. Ibshihi had an even longer entry. Ibshihi, Mustatraf, 270-271.

46 Ghazzi, Risala, 24. Kınalızade also counselled eating from what was in front of you during the main meal. Kınalı-zâde, Ahlâk, 216a.

47 Ghazzi, Risala, 20.
} 
he then shook the saliva off onto the food or wiped it on the mat. ${ }^{48}$ For this reason Ghazzi frowned upon the practice of licking one's fingers during the meal; while it was just within the margins of acceptability to do so after the meal was over, Ghazzi advised using a napkin (mizar al-mā'ida) instead. ${ }^{49}$

In short, shared plates did not make for simpler dining experiences. The fact that there were fewer structural elements at the table that disciplined the guests and carved out spheres of influence meant a greater reliance on each person's knowledge of etiquette, as well as the self-control to enforce it.

\section{The Trouble with the Body}

Although many of the problems Ghazzi addressed derived from material conditions unique to the Ottoman table, many others would have been familiar to his contemporaries the world over. These problems stemmed from what one might call the material qualities of human beings, that is, the bodily aspect of food consumption. There was no denying that eating fulfilled a basic and essential physiological need, and health was one of the things that concerned Ghazzi. The problem with "the gulper" (al-muballi'), who swallowed his food without having properly chewed it, was not just his voracity; chewing food too hastily caused it to have less nutritional value and could upset the stomach. ${ }^{50}$ Likewise, Ghazzi discouraged drinking cold water after hot food or with sweet fruits, since doing so ruined the teeth. ${ }^{51}$ Still, it was best, Ghazzi believed, to downplay the corporeal reality of eating.

Doing so meant concealing the fact that eating was a necessity. Many of the errors Ghazzi listed in his manual had to do with the lacking self-possession of those who could not wait to begin eating. Some took food while it was still too hot to eat comfortably, requiring them to blow air over it while the bite was already in their mouths. ${ }^{52}$ Others were so concentrated on the food that they stopped talking - if you asked them a question, they wouldn't answer but with a curt "yes." ${ }^{\prime 3}$ Such desperation compromised other marks of cultivation

\footnotetext{
48 Idem, 42.

49 Idem, 21.

50 Ghazzi, Risala, 19-20. Kınalızade also encouraged eating slowly. Kınalı-zâde, Ahlâk, 215b. Other manuals treating table etiquette had an even more explicit focus on health. Paulina Lewicka, "Challenges of Daily Life," in The Mamluk-Ottoman Transition, eds. Stephan Conermann and Gül Şen (Bonn, 2017), 71-72.

$51 \quad$ Ghazzi, Risala, 38 .

52 Idem, 24.

53 Idem, 29, 33.
} 
and class, as is most visible in the case of "the jumper" (al-wäthib), who was so fidgety during the meal that his turban almost fell off of his head. ${ }^{54}$ The ideal was to project an image of total independence and self-control, as if one's life did not depend on food.

Ghazzi also counseled minimizing the noise of eating. "The slurper" (alrashshäf), who noisily slurped his food and swallowed so loudly that all the guests could hear, must have been plaguing dinner parties for generations, since this was one of the terms Ghazzi adopted with few modifications from his predecessors. ${ }^{55}$ To him Ghazzi added "the smacker" (al-mufarqi ${ }^{\prime}$ ), who "doesn't close his mouth while chewing, so that the sound of his eating can be heard from the front door." 56 Instead, Ghazzi explained, "the polite [way to eat] is such that not even the one sitting closest to you can hear you."57

In the worst case, poor dining etiquette would cause diners to be reminded of their animalistic nature. Ghazzi fretted about those who chewed like camels, or those who, in order to avoid spilling broth on their clothes, stretched their necks out like them (thus soiling the table or the napkin instead). ${ }^{58}$ Similarly dispiriting was trying to enjoy one's meal while sitting across from "the cowhand" (al-baqqār), who stuck his tongue out and licked his lips over and over during the meal like the animal that was his namesake. ${ }^{59}$

What made eating together so dangerous is that the pleasure it evoked could quickly turn into disgust. This was especially true for that greatest of culinary delights: fats. We all know that fats are a source of enormous sensory satisfaction, and the clarified butter or sheep-tail fat used in Ottoman lands was no exception. ${ }^{60}$ Yet, fats could quickly became repulsive when, as we have seen, they dribbled down the chin of a table companion, or when eating with "the one who leaves greasy traces" (al-mudassim), who dipped his fatty meat into shared dishes and left traces of it everywhere. ${ }^{61}$ "The soiler" (al-muzaffir) extended this art to objects: he insisted upon requesting water during the meal rather than waiting as most did until it was over, thus getting grease all over the handle of the cup. ${ }^{62}$ This sort of thing seems to have been so great a problem

54 Idem, 27.

55 Idem, 21. See Jazzar, Fawa'id, 13a; Ibshihi, Mustatraf, 270.

56 Ghazzi, Risala, 20.

57 Ibid.

58 Idem, 20, 27.

59 Idem, 46.

6o Adam Drewnowski and Eva Almiron-Roig, "Human Perceptions and Preferences for FatRich Foods," in Fat Detection: Taste, Texture, and Post Ingestive Effects (Boca Raton, 2010); Faroqhi, Cultural History, 147.

61 Ghazzi, Risala, 25.

62 Ibid. See also Thévenot, Travels, 33; Pitts, Account, 19; Işın, Bountiful Empire, 44. 
that one of Ghazzi's contemporaries discouraged serving oily foods on fancy occasions altogether. ${ }^{63}$

Ottoman elites like Ghazzi seem to have felt considerable shame at some of their baser natural functions. However, they did not try to solve this problem by introducing more implements to the table and moving away from modes of eating that dirtied the hands, as Elias would have us believe. Rather, the solution lay in the bodily techniques that allowed them to conceal their reliance on foodstuffs and perform self-control.

\section{Conclusion: The Trouble with Eating Together}

Many of Ghazzi's concerns would have been wholly understandable to his contemporaries across Europe, and indeed sound familiar to us today. Communal eating always requires a certain proximity to others and a confrontation with one's shared corporality. Still, a number of the problems Ghazzi addressed stemmed from, or at least were compounded by, the particular material world of the early modern Middle East, including the relative dearth of objects at the table and the fact that dishes were shared. Far from making eating more straightforward, this meant that diners had to have a well-developed knowledge of what was acceptable as well as the bodily techniques to put that knowledge into practice. Taking Ghazzi's manual seriously allows us to decouple increasing material complexity from increasing social complexity. Cultures with fewer or simpler objects need not be simpler to navigate or less pronounced in their social hierarchies.

Navigating the delicate situations that arose from the Ottoman material world is precisely what Ghazzi's manual aimed to help his readers to do. Might we then consider Table Manners an enabler of the kind of geographic and social mobility that characterized his era, offering rules that would allow men of all backgrounds to sit around the same table? In terms of geographic mobility, this interpretation is more plausible. Although the overlap in the treatise's recommendations with those of Kinalızade's Sublime Ethics was no doubt first and foremost the result of their grounding in a shared intellectual tradition, it is not impossible that it was also in part the result of a direct exchange between its authors. The two scholars had a very intense personal relationship, and Kinalızade wrote much of his magnum opus during his four-year stay

63 Mustafa 'Ali, The Ottoman Gentleman of the Sixteenth Century: Muștafā 'Âli's Mevā'idü'nNefä'is fi Kavā'idi'-Mecālis (Tables of Delicacies Concerning the Rules of Social Gatherings), ed. and trans. Douglas Brookes (Cambridge, MA, 2003), 112. 
in Damascus in the early 1560 , at the same time that he was studying with Ghazzi. ${ }^{64}$ Even if Kinalızade never read Table Manners, with its digestible size and simple Arabic - the lingua franca of the Ottoman scholarly classes-it was certainly the type of text that would have been accessible to learned readers the empire over.

When it comes to enabling social mobility, though, Table Manners was likely less helpful. That social mixing did occasionally take place at mealtimes is suggested by the writings of Ghazzi's son, who claimed that whenever his father held celebratory banquets, he invited both rich and poor and treated them all equally. ${ }^{65}$ And yet, Ghazzi's was not the kind of book that an ambitious porter or street-vendor could pick up to begin cultivating a more refined lifestyle, since it contained little information practical or detailed enough to follow if one did not already know what to do. If anything, it would have been off-putting to such an audience, since it worked in part by bringing author and reader together in a shared disdain for those who were ignorant of proper manners.

And in fact, most of what we know from the early modern period indicates that people tended to dine with their social equals. The fact that Ghazzi's son went out of his way to highlight his father's inclusive banqueting suggests how unusual such a practice was, and he characterizes such occasions more as acts of charity than opportunities for genuine social interchange. More often, eating was used to sharpen social distinctions rather than to bridge them; many public soup kitchens served different social groups at different times of the day, beginning with the most honored guests and moving down the social hierarchy ${ }^{66}$ And in many ways, Ghazzi's manual helps us to understand why. The proximity of guests, the sharing of food items and the importance of proper etiquette meant that the cost of eating with people of a different background was potentially very high. The intensity with which meals were shared was matched only by the intensity with which access to them was restricted.

Ghazzi never formulated his unease with explicit reference to social class, other, perhaps, than in the case of the cowhand, whose eating habits may well have been patterned on the bovine companions with whom he spent much of his time. Rather, what Ghazzi expressed in Table Manners was a genuine, and often very visceral, discomfort with those who ate in ways that he perceived to

64 Helen Pfeifer, "Encounter After the Conquest," International Journal of Middle East Studies 47 (2015): 219-239.

65 Ghazzi, Kawakib, vol. 3, 5-6.

66 Amy Singer, Constructing Ottoman Beneficence: An Imperial Soup Kitchen in Jerusalem (Albany, 2002), 63. For the larger point, see Amalia Levanoni, "Food and Cooking during the Mamluk Era: Social and Political Implications," Mamluk Studies Review (2005): 201222; Abu Hussein, "Social Dining," 21-25. 
be incorrect. Though not a work of deliberate social exclusion, it in many ways functioned as just that. Refined behavior did not cost money, but it was also something that all the money in the world could not buy.

\section{Acknowledgements}

I would like to thank the anonymous reviewers as well as Melissa Calaresu and Alexandra Walsham for their feedback on this article. 